\title{
Optimising cleaning behaviour: minimising the costs and maximising ectoparasite removal
}

\author{
A. S. Grutter ${ }^{1, *}$, H. McCallum ${ }^{1}$, R. J. G. Lester ${ }^{2}$ \\ ${ }^{1}$ Department of Zoology and Entomology and ${ }^{2}$ Department of Microbiology and Parasitology, The University of Queensland, \\ Brisbane, Queensland 4072, Australia
}

\begin{abstract}
Little is known of how client fish minimise the costs of cleaning behaviour while maximising ectoparasite removal by cleaner fish. Previous studies have found that abundance on fish and infestation behaviour of gnathiid isopods, the main parasite eaten by cleaner fish, varies diurnally. We examined whether reduced foraging is a cost of cleaning behaviour in clients and whether the behaviour of the client fish, the thick-lipped wrasse Hemigymnus melapterus, towards the cleaner fish Labroides dimidiatus varied diurnally to maximise ectoparasite removal, possibly in response to the diurnal changes in the abundance and infestation patterns of gnathiids. We found that during the midday and afternoon, client foraging rates were negatively related to the duration and frequency of inspections, suggesting that cleaning may, at some times of the day, be energetically costly to the client in terms of reduced foraging opportunities. Surprisingly, we found that the duration and frequency of inspections of clients by cleaners did not vary among diel time periods. A model of gnathiid dynamics on individual fish is proposed. It shows that the observed diurnal pattern in gnathiid abundance on fish can be generated with the constant duration and frequency of inspections that was observed in this study. Thus clients would not have more gnathiids removed by modifying their cleaning behaviour.
\end{abstract}

KEY WORDS: Cleaning behaviour $\cdot$ Labroides dimidiatus $\cdot$ Cleaning symbiosis $\cdot$ Foraging behaviour . Gnathiidae

\section{INTRODUCTION}

Interspecific mutualisms play a fundamental role in all ecosystems (Boucher 1985). Numerous models on the evolution of mutualisms have been proposed (see Dugatkin 1997a,b). Despite the abundance of theories, few empirical studies have measured the benefits and costs of mutualism for both participants (Cushman \& Beattie 1991). In particular, there is a dearth of information on the costs involved in mutualisms (Janzen 1979, Addicott 1984, Morse 1985), specifically the costs that mutualism can impose on partners (Bronstein \& Ziv 1997). Such costs include locating, attracting, and/ or rewarding the partners that provide benefits (Bronstein \& Ziv 1997). Understanding how a mutualism functions requires information on the strategies that

*E-mail: a.grutter@mailbox.uq.edu.au participants use to reduce potential costs and maximise benefits. Insight on these strategies can be gained by examining the relationships among factors that are likely to influence the costs and benefits.

Fish cleaning behaviour, where cleaner fish remove parasites from apparently cooperating fish clients, is generally considered a mutualism. Yet little is known of the benefits, and even less of the costs involved in cleaning, particularly for the clients. Only recently was it demonstrated that cleaners affect the abundance of parasites of caged fish (Grutter 1999a), suggesting that client fish benefit from cleaning. Even less is known of the costs to the client. The removal of mucus from clients by cleaners (Gorlick 1980, Grutter 1997) may be costly to clients as mucus protects fish against pathogenic organisms and abrasive materials (Shephard 1994). Some client species spend a large amount of time being cleaned, about $30 \mathrm{~min}$ and 144 visits $\mathrm{d}^{-1}$ (Grutter 1995); this estimate does not include time 
spent locating cleaners. Whether time spent cleaning comes at a cost is unknown.

It is generally assumed that clients engage in cleaning for ectoparasite removal (but see Losey 1979). On the Great Barrier Reef, the cleaner fish Labroides dimidiatus removes many parasites from clients, mostly parasitic gnathiid isopods (Grutter 1996, Grutter 1997). Gnathiids remain on fish only long enough to feed and only the juveniles feed (Upton 1987). A species of gnathiid (Type 1 in Grutter et al. 2000) feeds on fish blood for only $1 \mathrm{~h}$ on the client fish Hemigymnus melapterus (A. Grutter unpubl. data). After feeding, gnathiids return to the benthos to digest their meal and moult to the next juvenile stage, repeating this process 3 times until they moult into adults which do not feed (Upton 1987). Interestingly, on the client $H$. melapterus the abundance of gnathiids declines daily between dawn and sunset (Grutter 1999b, Grutter \& Hendrikz 1999), most likely due, in part, to the actions of cleaners (Grutter 1999a). The infection patterns of gnathiids also vary throughout the day with higher rates at sunset and at night compared to the morning and midday (Grutter 1999b). Parasites affect the behaviour of $H$. melapterus in the laboratory with fish parasitised with gnathiids seeking cleaners more than unparasitised fish (Grutter 2001). Potts (1973) proposed that the increased activity of gnathiid isopods in aquarium fish at night explained the higher posing behaviour in clients and the subsequent higher cleaner-fish cleaning rates observed in the morning.

These points raise the question of whether the cleaning rates of clients in the field vary diurnally, possibly in response to 1 or more of the above factors related to gnathiids. In addition, it is not known whether cleaning comes at a cost, i.e. a reduction in non-cleaning behaviour, for example feeding, and whether such non-cleaning behaviours also vary diurnally.

To maximise the benefits of cleaning, the behavioural strategy (Hart 1997) of a client when 'being cleaned' should include minimising the costs of cleaning and maximising ectoparasite removal. To determine whether cleaning comes at a cost of reduced foraging, the relationship between cleaning and feeding behaviour was examined by comparing cleaning frequency and duration of cleaning to number of feeding bites taken by client fish per $30 \mathrm{~min}$. To determine whether client cleaning behaviour varied diurnally, possibly to maximise ectoparasite removal, we investigated the behaviour of the clients Hemigymnus melapterus from dawn to sunset and quantified their cleaning behaviour, feeding behaviour and interactions with other fishes. The observations were made in 2 different years, the second year to coincide with a study examining the diurnal variation in gnathiid abundance and infestation rates on fish (Grutter 1999b).

\section{MATERIALS AND METHODS}

The cleaning and feeding behaviour of the client fish Hemigymnus melapterus was recorded with a stopwatch and data transferred onto underwater paper on a clipboard following Grutter (1995). Observations were made by 2 scientists between dawn and sunset at Lizard Island, Great Barrier Reef, Australia $\left(14^{\circ} 40^{\prime} \mathrm{S}\right.$, $\left.145^{\circ} 28^{\prime} \mathrm{E}\right)$. Most observations were made on the reef flat along the lagoon at a depth of 1.5 to $2.5 \mathrm{~m}$. Focal fish sampling was undertaken with a snorkeler observing 1 fish for $30 \mathrm{~min}$ from a distance of 2 to $3 \mathrm{~m}$. The size of $H$. melapterus was estimated by comparing it to 2 points on the reef next to the fish and recording the distance on a slate. Only fish 10 to $20 \mathrm{~cm}$ in standard length (SL) were observed. A total of $58.5 \mathrm{~h}$ of observations were made with 45 observations between December 19, 1997 and February 5, 1998 and 72 observations between March 8 and 12, 1999. During the first year, observations were spread out randomly throughout the day while in the second year the majority of observations were made in a narrower time period, $<08: 00,11: 30$ to 13:00 h, and >17:00 h. For comparison between years, all observations were divided into $<$ 10:00 h, 10:00 to 14:00 h, and >14:00 h. Sunrise/sunset times for the above years ranged from 05:45-18:45 to $06: 11-18: 53 \mathrm{~h}$ and $06: 20-18: 38$ to $06: 21-18: 35 \mathrm{~h}$, respectively. Fish in the first and second years were observed between 05:48 and 18:25 $\mathrm{h}$ and between 06:17 and 18:30 h, respectively. Cleaner fish leave and re-enter their sleeping holes 5 to $14 \mathrm{~min}$ after sunrise and 7 to 9 min before the mean sunset (Grutter 1996) and so were available to clients most of the time they were observed.

Behaviours recorded were the number of feeding bites on invertebrates on the reef, taken per $30 \mathrm{~min}$ by clients Hemigymnus melapterus, the duration of cleaning inspections (visual examination of the body surfaces and or gills of the client) by the cleaner fish Labroides dimidiatus, whether client fish swam long distances (>30 m), whether client fish schooled with conspecifics, the time client fish went to sleep (hid in coral matrix), whether the client's gills were cleaned, whether clients 'posed', ready for cleaning, and whether they were cleaned by an adult or juvenile cleaner, with the latter 3 recorded only during the second year and the latter 2 recorded by 1 observer only.

To determine whether the cleaning behaviour of Hemigymnus melapterus varied between years and among diel time periods $(<10: 00 \mathrm{~h}, 10: 00$ to $14: 00 \mathrm{~h}$, and $>14: 00 \mathrm{~h}$ ), the sum of the duration of inspections and the frequency of inspections per $30 \mathrm{~min}$ were used in separate 2-factor analyses of covariance (ANCOVA) with fish SL as the covariable. To satisfy the assumption of homogeneity of variance and normality of the ana- 
lysis, outliers (zeros) were omitted and data were $\log _{10}$ transformed. Zeros were spread out relatively evenly among diel time periods $<10: 00 \mathrm{~h}, 10: 00$ to $14: 00 \mathrm{~h}$ and $>14: 00 \mathrm{~h}$ with 1,0 and 2 zeros per time period in the first year and 2, 1 and 3 zeros per diel time period, respectively, in the second year. The final sample sizes for each time period above were 16, 11 and 15 for the first year and 22, 23 and 21 for the second year, respectively. Whether the feeding behaviour (bites) of $H$. melapterus varied among diel time periods was also examined similarly with fish SL as the covariable.

The relationship between the rate that Hemigymnus melapterus was cleaned by cleaner fish and the feeding bite rate of $H$. melapterus (a measure of client foraging behaviour) was examined separately for the duration and frequency of inspections using partial correlation analyses adjusted for fish SL. The duration and frequency of inspection were $\log (x+1)$ transformed to satisfy the assumption that the variances of each variable were normally distributed, and that the data, across the levels of the other variables, were homogeneous. Each time period was examined separately for each different year. As the patterns were similar between years, year data were then pooled to increase the sample size and the analyses repeated.

The presence or absence of posing (Côté et al. 1998) or gill cleaning in Hemigymnus melapterus per $30 \mathrm{~min}$ observation was examined among diel time periods. Posing in $H$. melapterus is uncommon and not very distinctive. Gill cleaning, however, is more easily quantified, and likely a better indication of a client's willingness to be cleaned as gnathiids are often found in the gills (A. Grutter pers. obs.). The proportion of cleaning by juvenile or adult cleaners, summed across all interactions, was also examined among diel time periods. Juveniles were identified by their distinct dark blue and black colouration (Randall et al. 1997). Chi-square goodness-of-fit tests were used with expected values corrected for sampling effort (sample size divided by total sample size multiplied by total observed values).

\section{RESULTS}

The duration and frequency of inspections within each diel time period were relatively consistent over time. Both duration and frequency of inspections did not vary among years nor diel time periods (Table 1 , Fig. 1). The pooled duration of inspection was $41.7 \mathrm{~s}$ per $30 \mathrm{~min}$ and the pooled frequency of inspection was 5.7 inspections per $30 \mathrm{~min}$. The covariable fish SL was significant (Table 1), indicating that both the duration and frequency of inspections increased with fish size.

Hemigymnus melapterus fed by picking at dead branching coral or taking mouthfuls of coral rubble
Table 1. Analyses of covariance examining the (a) duration and (b) frequency of inspections per 30 min of Hemigymnus melapterus by the cleaner-fish Labroides dimidiatus during different sampling years (December 1997 to February 1998 and March 1999) and diel time periods (05:48 to 09:59 h, $10: 00$ to $13: 59 \mathrm{~h}$, and $14: 00$ to $18: 25 \mathrm{~h}$ ) with fish standard length (SL) as the covariable. Data were $\log _{10}$ transformed. SS: sum of squares

\begin{tabular}{|lcccc|}
\hline Source & df & SS & $F$ & $\mathrm{p}$ \\
\hline (a) Duration of inspection (s) & & & \\
Year & 1 & 0.233 & 1.874 & 0.174 \\
Time period & 2 & 0.013 & 0.051 & 0.951 \\
SL & 1 & 1.068 & 8.582 & 0.004 \\
Year $\times$ time period & 2 & 0.595 & 2.388 & 0.097 \\
Year $\times$ SL & 1 & 0.217 & 1.744 & 0.190 \\
Time period $\times$ SL & 2 & 0.047 & 0.188 & 0.829 \\
(b) Frequency of inspection & & & \\
Year & 1 & 0.038 & 0.487 & 0.487 \\
Time period & 2 & 0.035 & 0.227 & 0.797 \\
SL & 1 & 0.520 & 6.746 & 0.011 \\
Year $\times$ time period & 2 & 0.345 & 2.238 & 0.112 \\
Year $\times$ SL & 1 & 0.044 & 0.563 & 0.455 \\
Time period $\times$ SL & 2 & 0.054 & 0.353 & 0.703 \\
\end{tabular}

which were then expelled through the gill operculae. The feeding (bite) rates within a diel time period were relatively consistent. The variation among time periods did not vary greatly as shown by the standard errors in Fig. 2. The highest feeding rates of $H$. melapterus occurred at midday, even after adjusting for fish size (Fig. 2). Almost all fish fed actively during the morning, with $97 \%$ of the fish taking more than 50 feeding bites per observation period, suggesting they were moti-

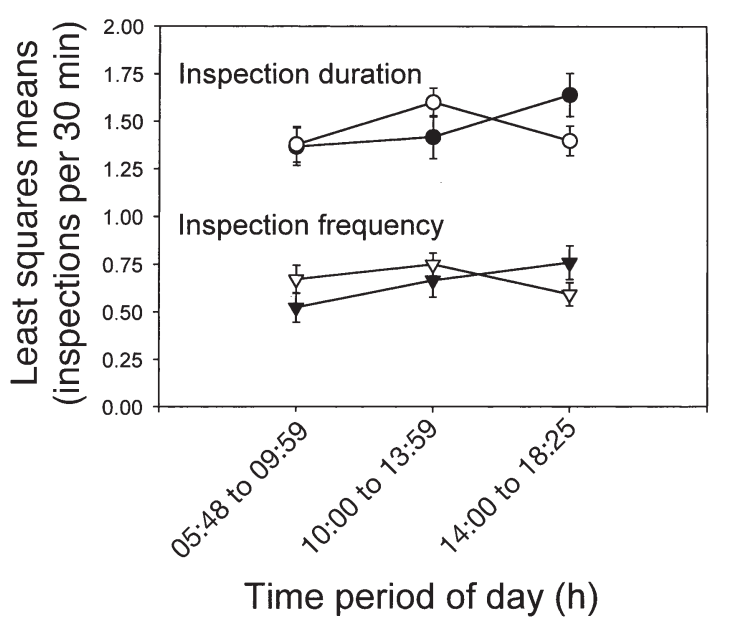

Fig. 1. Least squares means $( \pm \mathrm{SE})$ of the frequency $(n)$ and durations (s) of inspection per $30 \mathrm{~min}$ observation by the cleaner fish Labroides dimidiatus of the client fish Hemigymnus melapterus at 3 diel time periods and sampled during $2 \mathrm{yr}$. Closed symbols and open symbols represent sampling in December 1997 to January 1998 and March 1999, respectively. Data were $\log (x+1)$ transformed 
Table 2. Analysis of covariance examining the number of feeding bites per 30 min taken by Hemigymnus melapterus during different sampling years and diel time periods (see Table 1 for years and times), with fish standard length (SL) as the covariable

\begin{tabular}{|lcccc|}
\hline Source & df & SS & $F$ & $\mathrm{p}$ \\
\hline Year & 1 & 204.4 & 0.080 & 0.777 \\
Time period & 2 & 1219.4 & 0.240 & 0.787 \\
SL & 1 & 8564.1 & 3.366 & 0.069 \\
Year $\times$ time & 2 & 16767.9 & 3.295 & 0.041 \\
Year $\times$ SL & 1 & 187.4 & 0.074 & 0.787 \\
Time period $\times$ SL & 2 & 82.854 & 0.016 & 0.984 \\
\hline
\end{tabular}

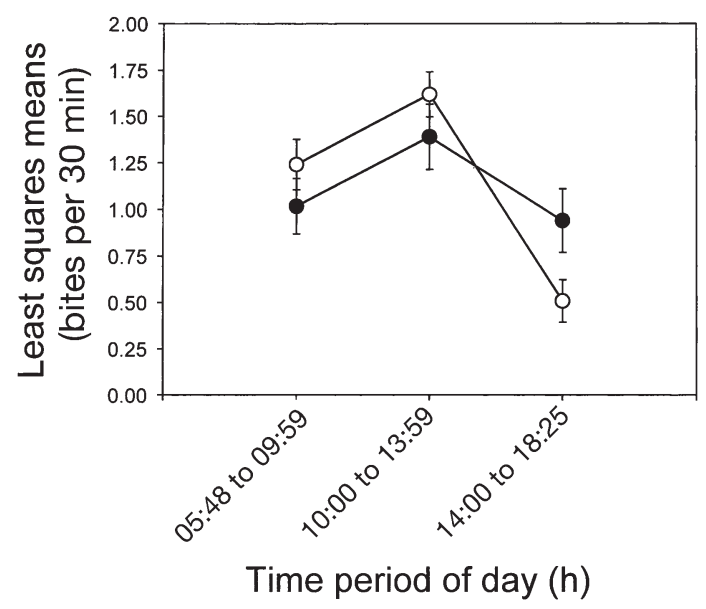

Fig. 2. Least squares means $( \pm \mathrm{SE})$ of feeding bites per $30 \mathrm{~min}$ observation taken by client fish Hemigymnus melapterus at 3 diel time periods and sampled during 2 years. Feeding bites were adjusted for fish standard length (SL). Symbols as in Fig. 1

vated to feed at this time. There was, however, a significant interaction between year and time period of day in the number of feeding bites taken by $H$. melapterus (Table 2, Fig. 2). This was largely a result of fewer feeding bites taken in the later part of the after-

Table 3. Partial correlation analyses of the relationship between frequency or duration of inspection by cleaner fish Labroides dimidiatus and number of feeding bites taken by Hemigymnus melapterus during different sampling years and diel time periods, adjusted for fish standard length (SL). In all analyses, $p>0.05$

\begin{tabular}{|c|c|c|c|c|c|}
\hline \multirow[t]{2}{*}{ Month/year } & \multirow{2}{*}{$\begin{array}{l}\text { Time of day } \\
\text { (h) }\end{array}$} & \multicolumn{2}{|c|}{$\log _{10}$ frequency } & \multicolumn{2}{|c|}{$\log _{10}$ duration } \\
\hline & & r & $\mathrm{df}^{t}$ & & df \\
\hline Dec 97 to Jan 98 & $05: 48$ to $09: 59$ & 0.452 & 14 & 0.232 & 14 \\
\hline Dec 97 to Jan 98 & $10: 00$ to $13: 59$ & -0.603 & 8 & -0.626 & 8 \\
\hline Dec 97 to Jan 98 & $14: 00$ to $18: 25$ & -0.407 & 14 & -0.440 & 14 \\
\hline Mar 1999 & $05: 48$ to $09: 59$ & 0.221 & 21 & 0.110 & 21 \\
\hline Mar 1999 & $10: 00$ to $13: 59$ & -0.302 & 21 & -0.242 & 21 \\
\hline Mar 1999 & $14: 00$ to $18: 25$ & -0.008 & 21 & -0.022 & 21 \\
\hline
\end{tabular}

noon during March 1999 compared to the samples taken earlier in the summer between December 1997 and January 1998.

After they were adjusted for client size, the frequency and duration of inspection of Hemigymnus melapterus by cleaner fish were not significantly related to the number of client feeding bites when examined separately for each time of day and year (Table 3). Many of the latter associations measured during midday and in the afternoon, however, showed a negative, but not significant, association (Table 3), with the patterns being similar between years (Table 3 ). Data were therefore pooled across years to increase the sample size. This revealed a significant negative relationship between frequency of inspection and feeding bites during midday and afternoon (Table 4) but no significant relationship between duration of inspection and feeding bites at all times (Table 4).

The proportion of fish that posed during each $30 \mathrm{~min}$ observation $(54,77$ and $91 \%$ during morning, midday, and afternoon, respectively) did not differ significantly among diel time periods $\left(\chi^{2}=1, d f=2, p=0.606\right)$. The sample size, however, was low with posing recorded in only 6 to 10 observations per diel time period (out of a total of 34 observations). The proportion of fish that had their gills cleaned during each 30 min observation $(68,78$ and $48 \%$ during morning, midday and afternoon, respectively) also did not differ significantly among diel time periods $\left(\chi^{2}=2.14, \mathrm{df}=2, \mathrm{p}=0.343\right)$. The proportion of all interactions that involved juvenile cleaner fish $(42,33$, and $28 \%$ during morning, midday and afternoon, respectively) did not vary among diel time periods either $\left(\chi^{2}=1.83, \mathrm{df}=2, \mathrm{p}=0.401\right)$. Fish were occasionally observed being cleaned by a different cleaner in subsequent encounters; therefore, clients were not loyal to cleaners.

Sample sizes were too small to conduct chi-square analysis to determine whether fish swam or schooled differently among diel time periods (all cells had expected values <5) (Zar 1999). There was, however, a tendency for fish to swim more in the early morning (observations beginning at 05:48 to 06:56 h) and late afternoon (observations beginning at 17:33 to $18: 47$ h), with 4 out of 20 fish (20\%) and 4 out of 22 fish (18\%) observed swimming at these times, respectively, compared to the rest of the day, where only 1 out of 75 fish (1.3\%) was observed swimming long distances (during an observation beginning at 12:39 h). The highest number of schooling Hemigymnus melapterus was observed between observations beginning at 17:33 and 18:10 h (5 out 
Table 4. Partial correlation analyses of the relationship between frequency or duration of inspection by cleaner fish Labroides dimidiatus and number of feeding bites taken by Hemigymnus melapterus at different diel time periods, adjusted for fish size (SL) and pooled across sampling years

\begin{tabular}{|crrcrrrrr|}
\hline $\begin{array}{c}\text { Time of day } \\
\text { (h) }\end{array}$ & \multicolumn{3}{c}{$\log _{10}$ frequency } & \multicolumn{3}{c|}{$\log _{10}$ duration } \\
05:48 to $09: 59$ & 0.187 & 38 & $>0.05$ & 0.197 & 38 & $>0.05$ \\
10:00 to $13: 59$ & -0.346 & 32 & $<0.05$ & -0.293 & 32 & $>0.05$ \\
$14: 00$ to $18: 25$ & -0.764 & 38 & $<0.001$ & -0.103 & 38 & $>0.05$ \\
\hline
\end{tabular}

of 13 fish observed during that time period), with only 2 fish in observations beginning at 06:25 and 06:26 $\mathrm{h}$ and 1 fish during the observation beginning at 12:39 $\mathrm{h}$. All client fish that were observed schooling with conspecifics had also been observed swimming long distances. Schooling fish rarely fed, and often lingered in a small area near live and/or dead coral. Occasionally, these areas were also inhabited by Labroides dimidiatus, but whether they were actively seeking cleaners was not clear. No agonistic encounters with conspecifics or with other species were observed, except for 2 fish that interacted ('dancing' and chaffing on the bottom) with an unidentified moray eel.

Immediately before going to 'sleep', client fish swam several times in and out of holes in the coral matrix before finally entering a hole where they remained lying on their side. They also showed 'shelter-seeking' behaviour (Hobson 1972) prior to entering holes, which involved milling around shelter (live and/or dead coral) with little to no feeding. In March 1999, client fish went to 'sleep' between 18:25 and 18:47 h, 12 and $10 \mathrm{~min}$ before and after the mean sunset, respectively, except for 1 very cloudy day when a client fish went to 'sleep' at 17:15 h (mean 18:23 h, SE 14 min, $\mathrm{n}=6$ ).

\section{DISCUSSION}

This is the first study to show a negative correlation between cleaning behaviour and client feeding rates. The negative relationship between the frequency by which the client Hemigymnus melapterus is cleaned by the cleaner fish Labroides dimidiatus and the feeding bite rate of $H$. melapterus during midday and afternoon, suggests that being cleaned at these times may result in reduced feeding in $H$. melapterus. A reduction in the number of feeding bites is likely to result in a reduced food intake and thus be energetically costly. Costs in terms of reduced feeding or foraging are common in fish and can be affected by many factors such as predation risk (Dugatkin \& Godin 1992), group size (Overholtzer \& Motta 2000), food distribution (Ryer
\& Olla 1997) and the presence of foraging partners (Eklöv 1992).

Clients likely have strategies to reduce costs incurred while cleaning. In this case, clients should maximize both cleaning and feeding rates. The client fish Hemigymnus melapterus fed almost constantly, thus it was difficult to determine wether they actively sought cleaners. Often, however, their foraging led them into cleaner fish territories where they continued to feed and this usually resulted in them being cleaned, often whilst continuing feeding. A tactic (Hart 1997) to maximise cleaning rates and reduce one of the potential costs of cleaning (time lost that could be spent feeding) may thus be to feed while being cleaned. Clients foraged almost constantly and so appeared motivated to feed at all times except after 17:00 h when feeding rates declined in some fish and a few fish instead swam for large distances and/or in schools. There was, however, no evidence that cleaning behaviour increased after foraging rates declined after 17:00 h. Furthermore, behaviours, other than feeding and cleaning, such as schooling and swimming, were relatively infrequent.

Why there was no relationship between cleaning frequency and feeding rates in the morning compared to midday and afternoon is puzzling. Cleaner fish inspect client fish more frequently in the early morning when the cleaners' guts are empty (Grutter 1996). Increased cleaning frequency by cleaner fish, however, was not observed in Hemigymnus melapterus in the morning. Possibly, as H. melapterus do not feed at night (A. Grutter pers. obs.), they may be 'hungrier' in the morning and forage differently. For example, $H$. melapterus may feed while being cleaned, more in the morning than later in the day. Also, although not significant, posing was also lowest in the morning suggesting clients were less 'willing' to pause to be cleaned in the morning. Again, such behaviour may be influenced by client hunger levels. Whether these proposed client behavioural strategies vary diurnally and whether they affect the efficacy of cleaning needs to be determined.

The infestation rate and abundance of parasitic gnathiid isopods on Hemigymnus melapterus varies throughout the day (Grutter 1999b, Grutter \& Hendrikz 1999). The cleaning behaviour of Labroides dimidiatus also varies with higher inspection rates in the early morning, when their guts are empty, compared to the rest of the day (Grutter 1996, 1997). Client fish with gnathiids also seek cleaners more than those without gnathiids (Grutter 2001). As L. dimidiatus mainly eat gnathiids it was predicted that the cleaning behaviour of $H$. melapterus would also vary diurnally in response to their varying gnathiid abundance or rates of gnathiid infestation.

Surprisingly, however, Hemigymnus melapterus showed no variation among diel time periods in the 
frequency or duration of inspections it received from Labroides dimidiatus. Although based on a smaller sample per time period compared to the present study, a study by Grutter (1995) at a similar time of year (January 1993) also found that the cleaning rates of $H$. melapterus did not differ among 4 diel time periods. The mean cleaning rates of $H$. melapterus found were also similar to those sampled in the present study. Posing, a measure of a client's 'willingness' to be cleaned (Losey 1972), which then increases the likelihood that a client will be cleaned (Côté et al. 1998), did not vary among diel time periods, nor did the proportion of fish that had their gills cleaned, a location rich in parasites (Grutter 1994) and a preferred site for gnathiids (A. Grutter pers. obs.). These findings suggest that clients do not maximise ectoparasite removal by modifying their cleaning behaviour in response to diurnal variation in client parasite loads and/or parasite infestation rates onto clients.

The role of juvenile cleaners has important implications in cleaner/gnathiid interactions, as juveniles eat fewer gnathiids compared to adults (Grutter 2000). Juvenile cleaners made up a significant proportion of the cleaning events ( 28 to $42 \%$ of events at each diel time period), demonstrating that juveniles play a significant role in the cleaning behaviour of Hemigymnus melapterus at this location. That the proportion of fish inspected by juvenile cleaners did not vary among diel time periods suggests that the above differences in cleaning behaviour were not due to differences in the size (age) of cleaners that inspected them.

Although the inspections by cleaners, gill cleaning of clients, and posing by clients did not vary diurnally, previous work on the same host fish has shown that the rate of gnathiid infection does vary on a diurnal cycle, with a maximum occurring close to dawn and another, smaller peak at dusk, and that gnathiid abundance per fish declines approximately exponentially during daylight hours if clients have access to cleaner fish (Grutter 1999b). A simple model was developed to bring these findings together, and to determine whether they are consistent with each other.

In general, the dynamics of the gnathiid burden on a host fish should follow an immigration-death model. The rate of change in gnathiid number with time, $\mathrm{d} G / \mathrm{d} t$, is given by:

$$
\frac{\mathrm{d} G}{\mathrm{~d} t}=I(t)-E(t) G(t)-C(t) f(G)
$$

Here, $G(t)$ is the number of gnathiids on the fish at time $t$ since dawn; $I(t)$ is the immigration rate to the fish, which is a function of time; $E(t)$ is the emigration rate from the fish; $C(t)$ is the intensity of the cleaning activity per unit time; and $f(G)$ is the functional response of the cleaners (the rate at which gnathiids are removed during cleaning events, as a function of the number of gnathiids present). The emigration rate $E(t)$ is likely to be independent of time of the day, being determined by the time taken for a gnathiid to engorge. This time appears to be $\leq 1 \mathrm{~h}$ (A. Grutter unpubl. data).

Grutter (1999b) placed uninfected fish in cages that prevented access by cleaner fish for periods of $4 \mathrm{~h}$, commencing at various times of the day. The number of gnathiids present per host after each exposure period was recorded. Assuming that $I$ is approximately constant over the period of exposure, the number of gnathiids per host at any time $(t)$ since commencement of the experiment would be given by the solution of Eq. (1) with $C(t)=0$ and $G(0)=0$ :

$$
G(t)=\frac{I}{E}(1-\exp [-E t])
$$

This means that the number of gnathiids present on fish should asymptote to $I / E$. Given that $E$ is close to $1 \mathrm{~h}^{-1}$, at the end of the $4 \mathrm{~h}$ exposure the burden would have reached $98 \%$ of the asymptote. Thus, the number of gnathiids per fish after a $4 \mathrm{~h}$ exposure period should be an approximate estimate of the immigration rate per hour in the 1 to $2 \mathrm{~h}$ leading up to the end of the exposure period. In Grutter (1999b), the mean gnathiid abundance per fish over the period 22:00 to $06: 00 \mathrm{~h}$ was halved to account for an $8 \mathrm{~h}$ exposure period. Eq. (2) suggests that this adjustment should not have been made. Thus Grutter's (1999b) estimated cumulative number of gnathiids per fish is conservative.

The data in Grutter (1999b) suggest that $I(t)$ peaks around dawn, declines during the daylight hours, and peaks again close to dusk, whereas the number of gnathiids on fish subject to cleaning declines throughout the daylight hours. Further, Grutter (1999a) demonstrated that at sunset there is a significant decrease in gnathiid abundance on fish subject to cleaning compared to fish on patch reefs without cleaners. One might expect that the intensity of cleaning would be proportional to the intensity of gnathiid infection on host fish, and should likewise show peaks at dusk and dawn. However, no evidence of a diurnal pattern in cleaning intensity was found in the present study. A possible interpretation of these findings is that the gnathiid abundance per fish is usually sufficient that the functional response $f$ is close to its asymptote, so that the prey intake per unit time per cleaner does not change substantially during the day (see Fig. 3).

It is unlikely that the lack of variation in cleaning behaviour throughout the day is due to fish not being aware of gnathiids. Observations of Hemigymnus melapterus that were exposed to gnathiids show that they are aware of them and actively avoid them by shaking their bodies and/or swimming away (A. Grutter unpubl. data). More importantly, H. melapterus ex- 


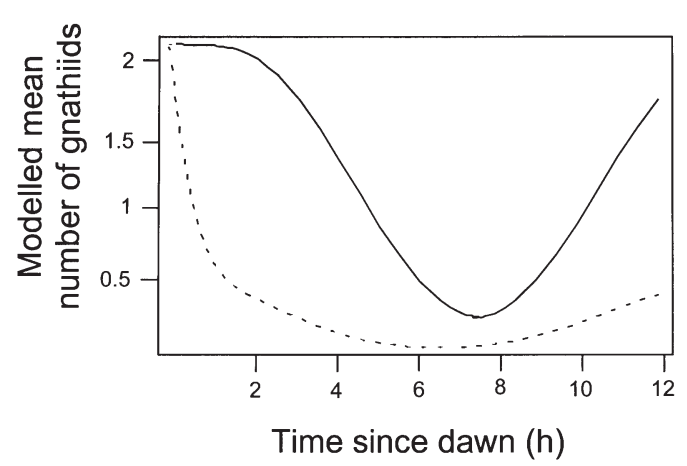

Fig 3. Modelled mean numbers of gnathiids per client fish Hemigymnus melapterus, as a function of time since dawn, in the absence of cleaning (- ${ }^{-}$, and with cleaners present (- - - -). The lines are solutions of Eq. (1), with a sinusoidal infection rate peaking at dawn and dusk, and a Type II cleaning response that asymptotes at a gnathiid abundance per fish close to the minimum abundance reached in the absence of cleaning. Note that the modelled gnathiid abundance with cleaning occurring increases towards sunset, but does not reach the point close to that attained at dawn

posed to gnathiids also spend more time seeking a cleaner fish compared to unparastised $H$. melapterus (Grutter 2001).

In the wild, Hemigymnus melapterus also have other ectoparasites, including relatively high numbers of Hatschekia hemigymni copepods in their gills and occasionally other isopods, copepods, turbellarians, or monogeneans (Grutter 1994). In contrast to gnathiids, which only remain on the host while feeding (Paperna \& Por 1977), the majority of these parasites remain on the host for most of their lifetime (Lester \& Roubal 1995) and most of these are eaten, although in low numbers, by cleaners (Grutter 1997). The role that these other parasites play in client cleaning behaviour is unclear. The response of clients to these, however, likely differs to that of gnathiids. The latter, which only remain on fish for around $1 \mathrm{~h}$ (A. Grutter unpubl. data), would have recently settled on fish and thus present a new stimulus to the fish compared to a long-term resident parasite (Grutter 2001). Such a new stimulus, which the host may not yet be habituated to, may be a more powerful stimulus for clients to seek cleaners than resident parasites (Grutter 2001).

The lower bite rates in the afternoon in March 1999 compared to those from December 1997 to January 1998 are likely a sampling artefact due to the earlier sunsets in March leading fish to prepare to enter sleeping holes earlier (Hobson 1991). As Gottlieb (1992) found, larger Hemigymnus melapterus took fewer feeding bites than smaller fish. This may be due to variation in fish size classes in the diet composition, foraging microhabitat and prey sizes of $H$. melapterus (Gottlieb 1992).
Acknowledgements. Many thanks to M. Johnson for assisting with field observations, the Lizard Island Research Staff for their support, and J. Hendrikz for statistical advice. This work was funded by the Australian Research Council in a grant and fellowship to A.S.G.

\section{LITERATURE CITED}

Addicott JF (1984) Mutualistic interactions in population and community processes. In: Price PQ, Slobodchikoff CN, Gaud WS (eds) A new ecology: novel approaches to interactive systems. John Wiley \& Sons, New York, p 437-453

Boucher DH (1985) The biology of mutualism. Croom Helm, London

Bronstein JL, Ziv Y (1997) Costs of two non-mutualistic species in a yucca/yucca moth mutualism. Oecologia 112: 379-385

Côté IM, Arnal C, Reynolds JD (1998) Variation in posing behaviour among fish species visiting cleaning stations. J Fish Biol 53(Suppl A):256-266

Cushman JH, Beattie AH (1991) Mutualisms: assessing the benefits to hosts and visitors. Trends Ecol Evol 6(6):193-195

Dugatkin LA (1997a) Cooperation among animals. Oxford University Press, Oxford

Dugatkin LA (1997b) The evolution of cooperation. BioScience 47:355-362

Dugatkin LA, Godin JGJ (1992) Predator inspection, shoaling and foraging under predation hazard in the Trinidinian guppy, Poecilia reticulata. Environ Biol Fish 34:265-276

Eklöv P (1992) Group foraging versus solitary foraging efficiency in piscivorous predators: the perch, Perca fluviatilis, and the pike, Esox lucius, patterns. Anim Behav 44: 313-326

Gorlick DL (1980) Ingestion of host fish surface mucus by the Hawaiian cleaning wrasse, Labroides phthirophagus (Labridae), and its effect on host species preference. Copeia 1980:863-868

Gottlieb M (1992) Utilization of habitat and food resources in a guild of wrasses (Labridae). Honours thesis, James Cook University, Townsville, p 1-95

Grutter AS (1994) Spatial and temporal variations of the ectoparasites of seven reef fish species from Lizard Island and Heron Island, Australia. Mar Ecol Prog Ser 115:21-30

Grutter AS (1995) Relationship between cleaning rates and ectoparasite loads in coral reef fishes. Mar Ecol Prog Ser 118:51-58

Grutter AS (1996) Parasite removal rates by the cleaner wrasse Labroides dimidiatus. Mar Ecol Prog Ser 130:61-70

Grutter AS (1997) Spatio-temporal variation and feeding selectivity in the diet of the cleaner fish Labroides dimidiatus. Copeia 1997(2):346-355

Grutter AS (1999a) Cleaner fish really do clean. Nature 398: 672-673

Grutter AS (1999b) Infestation dynamics of parasitic gnathiid isopod juveniles on a coral reef fish Hemigymnus melapterus. Mar Biol 135:545-552

Grutter AS (2000) Ontogenetic variation in the diet of the cleaner fish Labroides dimidiatus and its ecological consequences. Mar Ecol Prog Ser 197:241-246

Grutter AS (2001) Parasite infection rather than tactile stimulation is the proximate cause of cleaning behaviour in reef fish. Proc R Soc Lond B 268:1361-1365

Grutter AS, Hendrikz J (1999) Diurnal variation in the abundance of parasitic gnathiid isopod larvae on coral reef fish: its implications in cleaning interactions. Coral Reefs 18: 187-191 
Grutter AS, Morgan J, Adlard R (2000) Characterising parasitic gnathiid isopod species and matching life stages using ribosomal DNA ITS2 sequences. Mar Biol 136: 201-205

Hart PJB (1997) Foraging tactics. In: Godin JGJ (ed) Behavioural ecology of teleost fishes. Oxford University Press, Oxford, p 104-133

Hobson ES (1972) Activity of Hawaiian reef fishes during the evening and morning transitions between daylight and darkness. Fish Bull 70(3):715-740

Hobson ES (1991) Trophic relationships of fishes specialized to feed on zooplankters above coral reefs. In: Sale PF (ed) The ecology of fishes on coral reefs. Academic Press, Sydney, p 69-95

Janzen DH (1979) How to be a fig. Annu Rev Ecol Syst 10: $13-51$

Lester RJG, Roubal FR (1995) Phylum Arthropoda. In: Woo PTK (ed) Fish diseases and disorders. CAB International, Wallingford, p 475-599

Losey GS Jr (1972) The ecological importance of cleaning symbiosis. Copeia 1972:820-833

Losey GS Jr (1979) Fish cleaning symbiosis: proximate causes of host behaviour. Anim Behav 27:669-685

Morse DH (1985) Costs in a milkweed-bumblebee mutualism. Am Nat 125:903-905

Editorial responsibility: Charles Birkeland (Contributing

Editor), Honolulu, Hawaii, USA
Overholtzer KL, Motta PJ (2000) Effects of mixed-species foraging groups on the feeding and aggression of juvenile parrotfishes. Environ Biol Fish 58:345-354

Paperna I, Por FD (1977) Preliminary data on the Gnathiidae (Isopoda) of the Northern Red Sea, the Bitter Lakes and the Eastern Mediterranean and the Biology of Gnathia piscivora n. sp. Rapp Comm Int Mer Medit 24(4):195-197

Potts GW (1973) Cleaning symbiosis among British fish with special reference to Crenilabrus melops (Labridae). J Mar Biol Assoc UK 53:1-10

Randall JE, Allen GR, Steene RC (1997) Fishes of the Great Barrier Reef and Coral Sea. Crawford House Publishing, Bathurst, p 1-557

Ryer $\mathrm{CH}$, Olla BL (1997) Altered search speed and growth: social versus independent foraging in two pelagic juvenile fishes. Mar Ecol Prog Ser 153:273-281

Shephard KL (1994) Functions for fish mucus. Rev Fish Biol Fish 4:401-429

Upton NPD (1987) Gregarious larval settlement within a restricted intertidal zone and sex differences in subsequent mortality in the polygynous saltmarsh isopod Paragnathia formica (Crustacea: Isopoda). J Mar Biol Assoc UK 67:663-678

Zar JH (1999) Biostatistical analysis. Prentice Hall International, Sydney

Submitted: July 2, 2001; Accepted: November 21, 2001

Proofs received from author(s): May 2, 2002 